\title{
Partial Characterization of Amylases of two Indigenous Central Amazonian Rhizobia Strains
}

\author{
Arlem Nascimento de Oliveira ${ }^{1 *}$, Luiz Antonio de Oliveira ${ }^{1}$ and Jerusa Souza Andrade ${ }^{2}$ \\ ${ }^{1}$ Coordenação de Pesquisas em Ciências Agronômicas do Instituto Nacional de Pesquisas da Amazônia; \\ ${ }^{2}$ Coordenação de Pesquisas em Tecnologia de Alimentos do Instituto Nacional de Pesquisas da Amazônia; Av. \\ André Araújo, 2936; C.P. 478; 69060-001; Manaus - AM - Brasil
}

\begin{abstract}
Amylase production and partial characterization of crude enzyme preparations from two rhizobia strains $(R-926$ and $R$-991) were evaluated. For both the strains, maximal amylase activities were achieved during the early-to-midexponential growth phase; both were active over a $\mathrm{pH}$ range from 4.5 to 8.5 and temperature from 30 to $50{ }^{\circ} \mathrm{C}$. None of the ions studied $\left(\mathrm{K}^{+}, \mathrm{Na}^{+}, \mathrm{Ca}^{2+}, \mathrm{Hg}^{2+}, \mathrm{Mg}^{2+}, \mathrm{Mn}^{2+}, \mathrm{Cu}^{2+}\right.$ and $\left.\mathrm{Zn}^{2+}\right)$ was required for the catalytic activity of strain R-926; amylase activity of strain R-991 was stimulated in the presence of $\mathrm{K}^{+}, \mathrm{Hg}^{2+}$ and $\mathrm{Zn}^{2+}$. The surfactants SDS, Triton $X-100$ and Tween-80 did not have a pronounced inhibitory effect on enzyme activities; SDS and Tween80 caused the highest stimulatory effects. Amylase activities from the rhizobia strains were reduced by up to $30 \%$ in the presence of EDTA; amylase activity of $\mathrm{R}-926$ was also inhibited by $\mathrm{HgCl}_{2}$, suggesting that $\mathrm{Ca}^{2+}$ and cysteine residues could be important for activity of this strain.
\end{abstract}

Key words: Rhizobium, Bradyrhizobium, Amylase production, Enzymatic properties

\section{INTRODUCTION}

Amylases are among the most important enzymes used in modern biotechnology, particularly in the processes involving starch hydrolysis. The extensive application of amylases in the food, starch liquefaction and saccharification, detergent, textile, paper, brewing and distilling industries has paved a way for their large-scale commercial production (Gupta et al., 2003). Although amylases originate from different sources (plants, animals and microorganisms), microbial amylases generally meet industrial demands best, due to their short growth period, productivity and thermostability (Burhan et al., 2003). Today, a large number of microbial amylases are available commercially and they have almost completely replaced chemical hydrolysis of starch in the starch processing industry (Pandey et al., 2000).

Microbial amylases are produced mainly from cultures of Aspergillus, Bacillus, Clostridium, Pseudomonas, Rhizopus and Streptomyces species (Pandey et al., 2000). Because of the industrial importance of amylases, there is an increasing worldwide interest in the screening of new microorganisms producing amylases suitable for new industrial applications (Burhan et al., 2003; Gupta et al., 2003). Rhizobia are gram-negative soil bacteria belonging to the family Rhizobiaceae that are capable of infecting and nodulating the roots of their hosts, leguminous plants. Cellulolytic and pectinolytic (Jimenéz-Zurdo et al., 1996), proteolytic (Glenn and Dilworth, 1981) and ureolytic (Toffanin et al., 2002) enzyme activities

\footnotetext{
* Author for correspondence: arlem@inpa.gov.br
} 
have been detected in pure rhizobial culture. Nonetheless, studies on rhizobia amylases are still scarce. Recently, Oliveira et al. (2006) reported the occurrence of extracellular amylases in rhizobia strains in solid and liquid media (Oliveira et al., 2007). The aim of this study was the production and characterization of extracellular amylases from two indigenous Central Amazonian rhizobia strains.

\section{MATERIALS AND METHODS}

Indigenous rhizobia strains, culture conditions and inoculum preparation

The rhizobia strains used in this study were Rhizobium sp. INPA R-926 and Bradyrhizobium sp. INPA R-991 isolated from soils of the Central Amazonian floodplain. The rhizobial strains were identified by partial sequencing of the $16 \mathrm{~S}$ rRNA gene (Oliveira et al., 2007). Stock cultures were maintained on extract-mannitol agar (YMA) slants (Vincent, 1970) at $4{ }^{\circ} \mathrm{C}$. The medium used for enzyme production was composed of $\left(\mathrm{g} \mathrm{L}^{-1}\right)$ : 10.0 maltose, $0.4 \mathrm{~K}_{2} \mathrm{HPO}_{4}, 0.1 \mathrm{~K}_{2} \mathrm{HPO}_{4}, 0.2 \mathrm{MgSO}_{4} .7$ $\mathrm{H}_{2} \mathrm{O}, 0.1 \mathrm{NaCl}$ and 0.4 yeast extract. The $\mathrm{pH}$ of the medium was adjusted to 6.8 with $\mathrm{KOH}$ and autoclaved at $120{ }^{\circ} \mathrm{C}$ for $20 \mathrm{~min}$. Fifty milliliters of medium were taken in $150 \mathrm{~mL}$ Erlenmeyer flasks and inoculated with $1 \mathrm{~mL}$ of inoculum culture, grown in YM medium (Vincent, 1970) for 3 (R$\left.926=1.4 \times 10^{9} \mathrm{CFU}\right)$ and 5 days $(\mathrm{R}-991=2.0 \mathrm{x}$ $10^{9} \mathrm{CFU}$ ), and incubated at $28{ }^{\circ} \mathrm{C}$ with rotary shaking (65 cycles per min). Cultures were harvested and centrifuged (12000 rpm, $10 \mathrm{~min}$ ) at 24-h intervals for 8 (R-926) and 12 days (R-991) of growth. At these intervals, the cell-free culture supernatant served as the enzyme source to evaluate the reducing sugars, amylase activity, total extracellular protein and final $\mathrm{pH}$ of the medium. The turbidity of the cultures was determined by measuring the increase in optical density at $560 \mathrm{~nm}$ in a Spectrum UV-Vis Spectrophotometer. Biomass production $\left(\right.$ g. $\left.\mathrm{L}^{-1}\right)$ was also determined by drying the pellet at $105{ }^{\circ} \mathrm{C}$ overnight until constant weight.

For enzymatic characterization studies, the rhizobia strains were incubated for $48 \mathrm{~h}$ in the same experimental conditions mentioned above.

\section{Analytical methods}

Amylase activity was determined by monitoring starch hydrolysis and production of reducing sugars from starch. The reaction mixture consisted of $300 \mathrm{~mL}$ of previously gelatinized corn starch solution (1\%), $350 \mathrm{~mL}$ of $0.05 \mathrm{M}$ phosphate buffer (pH 6.5) and $350 \mathrm{~mL}$ of crude enzyme preparation. After $30 \mathrm{~min}$ of incubation at $37{ }^{\circ} \mathrm{C}$ in a water bath, the reducing sugars (glucose equivalents liberated) were estimated by Nelson's modified Somogyi's method (Nelson, 1944). The colour was read at $511 \mathrm{~nm}$ using a Spectrum UV-Vis Spectrophotometer. Glucose was used as the standard. The blank contained $300 \mathrm{~mL}$ of corn starch solution and $700 \mathrm{~mL}$ of $0.05 \mathrm{M}$ phosphate buffer ( $\mathrm{pH}$ 6.5). One enzyme unit (U) was defined as the amount of enzyme that released $1 \mu \mathrm{mol}$ of reducing sugar $\mathrm{mL}^{-1} \mathrm{~min}^{-1}$ under the standard assay conditions described above. Total extracellular protein was measured by the biuret method (Gornall et al., 1949), using bovine serum albumin (BSA) in the standard curve.

\section{Effect of pH on activity and stability}

The effect of $\mathrm{pH}$ on enzyme activity was determined by measuring the activity at $37{ }^{\circ} \mathrm{C}$ using citrate - phosphate $(0.05 \mathrm{M}, \mathrm{pH} 3.5-5.5)$, phosphate $(0.05 \mathrm{M}, \mathrm{pH} 6.5-7.5)$ and Tris- $\mathrm{HCl}$ (0.05 M, pH $8.5-9.5)$ buffers for $30 \mathrm{~min}$. Stability of enzyme without substrate was also studied by pre-incubating the crude enzyme at different $\mathrm{pH}$ values ranging from 3.5 to 9.5 for $24 \mathrm{~h}$, at room temperature, with the residual activity determined under standard conditions.

\section{Effect of temperature on activity and stability}

The effect of temperature on enzyme activity was determined by performing the standard assay procedure for $30 \mathrm{~min}$ within a temperature range of $30-60{ }^{\circ} \mathrm{C}$ in phosphate buffer $(0.05 \mathrm{M}, \mathrm{pH}$ 7.5). Thermostability in the absence of substrate was investigated at $\mathrm{pH} 7.5$ after pre-incubation of the crude enzyme at temperatures ranging from 30 to $60{ }^{\circ} \mathrm{C}$ for $2 \mathrm{~h}$ in a water bath, and then the samples were removed and the remaining activity assayed under standard conditions.

\section{Effect of cations on enzyme activity}

The influence of cations $\left(\mathrm{K}^{+}, \mathrm{Na}^{+}, \mathrm{Ca}^{2+}, \mathrm{Hg}^{2+}\right.$, $\mathrm{Mg}^{2+}, \mathrm{Mn}^{2+}$ and $\mathrm{Zn}^{2+}$ ) on amylase activity was studied by adding them to the reaction solution to final concentrations of 1 and $5 \mathrm{mM}$. All metals used were in the chloride and sulphate forms. The activity was assayed under optimum conditions of 
both $\mathrm{pH}$ and temperature as required by the rhizobia amylases. Activity in the absence of any additives (control) was taken as $100 \%$.

\section{Effect of surfactants on enzyme activity}

To investigate the effect of surfactants on enzyme activity, the detergents, Triton X-100, Sodium Dodecyl Sulfate (SDS) and Tween- 80 were added to the enzyme at final concentrations of 1 and $2 \%$. Amylase activity was then measured in the same way as mentioned earlier.

\section{Effect of inhibitors on enzyme activity}

The assay procedure was the same as described above except that the reaction mixture included different inhibitors, such as Ethylene Diamine Tetraacetic Acid (EDTA), $\mathrm{HgCl}_{2}$ and p-Methyl Sulphonyl Fluoride (PMSF), at final concentrations of 5 and $10 \mathrm{mM}$. Amylase activity was determined as described previously.

\section{Experimental design and statistical analyses}

The enzymatic assays were organized using a complete randomized design with three replicates and repeated twice for reproducibility. Tukey's test was used to identify means that differed significantly $(\mathrm{p}<0.05)$. Pearson's correlation coefficients were also considered significant at $\mathrm{p}<$ 0.05 .

\section{RESULTS AND DISCUSSION}

\section{Growth curve and amylase production}

Maximum biomass production and optical density $\left(\mathrm{DO}_{560}\right)$ for both the strains were achieved after the $4^{\text {th }}$ day of cultivation (Figs 1 and 2). Bradyrhizobium strain exhibited maximum total extracellular protein on the $2^{\text {nd }}$ day of cultivation, whereas the Rhizobium strain exhibited its maximum on the $7^{\text {th }}$ day of incubation. For both the strains, maximal amylase activities were achieved during the early-to-middle-exponential growth phase and then decreased gradually, as observed for other bacterial amylases (Castro et al., 1999; Aguilar et al., 2000).

Final $\mathrm{pH}$ of the culture medium after 72-h growth of Rhizobium strain increased from 6.8 to 7.4 (Fig. 1). The rise of $\mathrm{pH}$ could be due to the utilization of organic acids or production of alkaline compounds, as suggested by Cibis et al. (2004) and Rahman et al. (2005). On the other hand, the final $\mathrm{pH}$ of the culture medium of Bradyrhizobium strain decreased to 5.7 during this period (Fig. 2). This could be attributed to the production of acids during the bacterial growth.

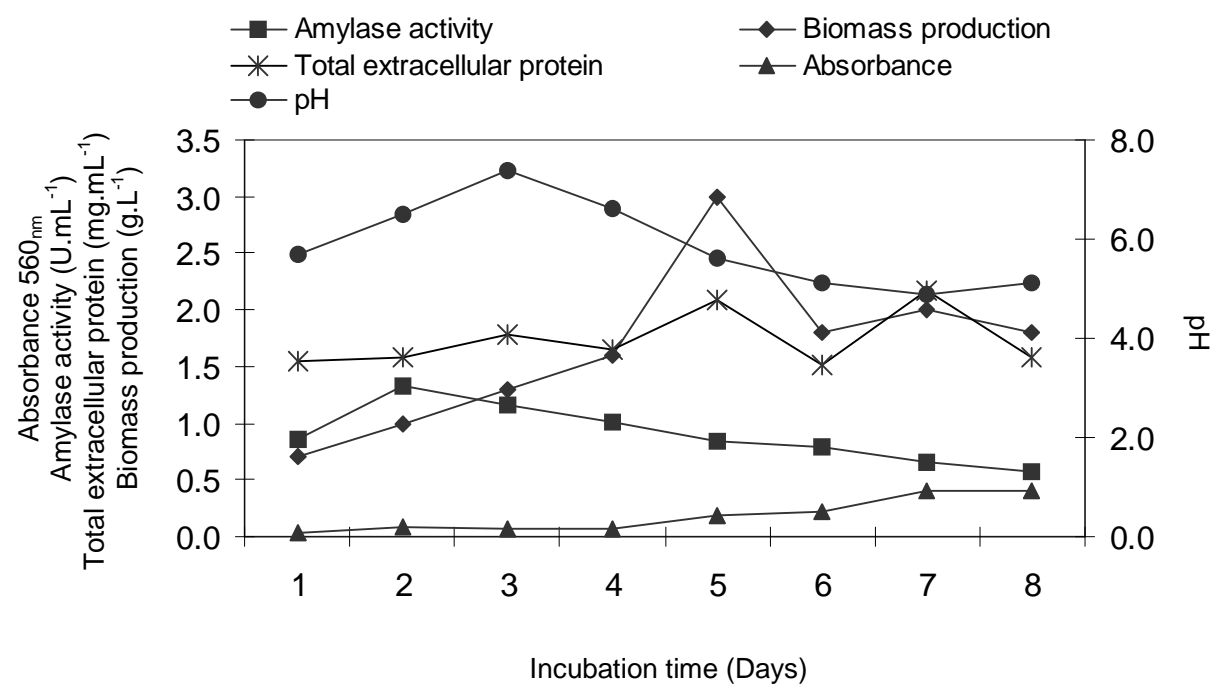

Figure 1 - Time course of amylase production by Rhizobium sp. strain INPA R-926 using maltose as sole carbon source. Amylase activity $(\mathbf{\square})$; Biomass production $(\bullet)$; Total extracellular protein $(*)$; Absorbance $(\boldsymbol{\Delta}) ; \mathrm{pH}(\bullet)$. 


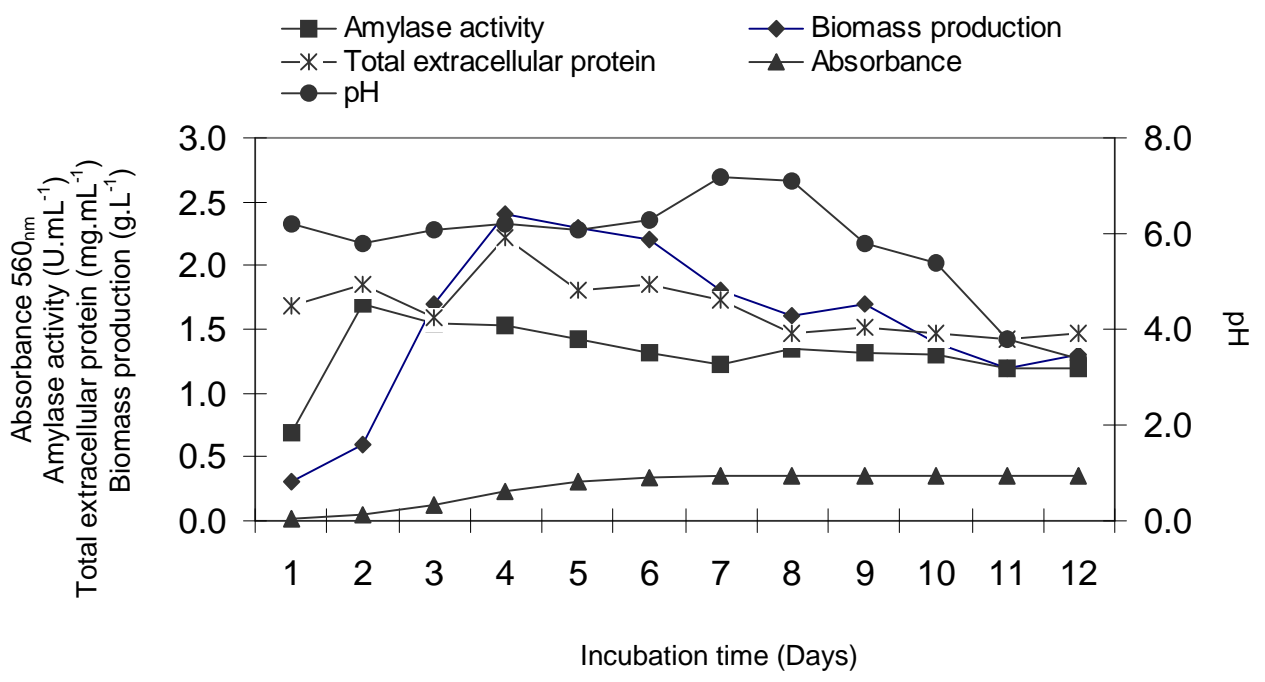

Figure 2 - Time course of amylase production by Bradyrhizobium sp. strain INPA R-991 using maltose as sole carbon source. Amylase activity $(\mathbf{\square})$; Biomass production $(\bullet)$; Total extracellular protein $(*)$; Absorbance $(\boldsymbol{\Delta})$; $\mathrm{pH}(\bullet)$.

\section{Correlations among the parameters evaluated} There was no significant correlation between amylase production and final $\mathrm{pH}$ of the medium of the Bradyrhizobium strain. On the other hand, amylase production and final $\mathrm{pH}$ of the medium were closely associated for the Rhizobium strain (Table 1). Similar findings have been previously documented by Sunna and Hashwa (1990), Wijbenga et al (1991) and Stamford et al. (2001) for other microbial amylases.

Amylase production from the Rhizobium strain presented significant negative correlations with biomass and optical density $\left(\mathrm{OD}_{560}\right)$. These negative correlations could be because of the higher amylase production that occurred during the early-to-mid-exponential growth phase, while during the late exponential and early stationary growth phase, rhizobial biomass production was higher. The negative correlation observed between amylase production and optical density $\left(\mathrm{OD}_{560}\right)$ supported this observation (Table 1). On the other hand, correlation between amylase production and bacterial biomass from Bradyrhizobium strain was significantly positive, confirming several authors who also found this type of linear correlation in Bacillus stearothermophilus (Davis et al., 1980), B. amyloliquefaciens (Castro et al., 1993), Nocardiopsis sp. (Stamford et al., 2001), Bacillus sp. (Cordeiro et al., 2002) and in Rhodothermus marinus (Gomes et al., 2003). There was no significant correlation between amylase production and total extracellular protein for either rhizobia strains (Table 1).

Table 1 - Correlation analysis between amylase production and final $\mathrm{pH}$ of the culture medium, optical density (DO), biomass production and total extracellular protein secretion in two indigenous Central Amazonian rhizobia strains.

\begin{tabular}{lcccc}
\hline Rhizobia strains & Final pH & $\begin{array}{c}\text { Biomass } \\
\text { production }\end{array}$ & OD $_{\mathbf{5 6 0}}$ & Total extracellular protein \\
\hline INPA R-926 $(\mathrm{n}=24)$ & $0.86^{\mathrm{a}}$ & -0.45 & -0.79 & -0.23 \\
& $(0.000)^{\mathrm{b}}$ & $(0.026)$ & $(0.000)$ & $(0.277)$ \\
INPA R-991 $(\mathrm{n}=36)$ & 0.09 & 0.47 & 0.08 & 0.30 \\
& $(0.702)$ & $(0.019)$ & $(0.703)$ & $(0.075)$ \\
\hline
\end{tabular}

${ }^{a}$ Pearson's coefficient of correlation; ${ }^{b}$ Probability level 
Effect of pH on amylase activity and stability The $\mathrm{pH}$ profiles showed a broad range of activity at $37{ }^{\circ} \mathrm{C}$ for $30 \mathrm{~min}$, exhibiting $70-88 \%$ of maximum activities in the $\mathrm{pH}$ range 4.5-8.5 (Figs 3 and 4). The $\mathrm{pH}$ for the optimum activity of amylase from the Rhizobium strain was 7.5 (Fig. $3)$. A similar result was reported by Cordeiro et al. (2002) for an amylase produced by Bacillus sp. The optimum $\mathrm{pH}$ for amylase activity from the Bradyrhizobium strain was also 7.5 (Fig. 4), but significant levels of activity (above $88 \%$ ) were still detected between $\mathrm{pH}$ 5.5-8.5. The amylases produced by several bacterial sources, including Bacillus sp., have a variety of $\mathrm{pH}$ profiles. The maximum activity of most of the enzymes earlier reported has been in the $\mathrm{pH}$ range 5.0-12.0 (Kim et al., 1995; Leveque et al., 2000; Hagihara et al., 2001; Gomes et al., 2003; Goyal et al., 2005). In spite of earlier reports on the amylase activity at low $\mathrm{pH}$ for some amylases (Buonocore et al., 1976; Ohdan et al., 1999), there are few reports on amylases that have maximum activity at $\mathrm{pH}$ lower than 5.0 (Vihinen and Mäntsälä, 1989; Matzke et al., 1997; Jorgensen et al., 1997). In this study, the amylases produced by these rhizobia strains retained up to $78 \%$ of their maximum catalytic activities at $\mathrm{pH} 4.5$ (Figs 3 and 4).

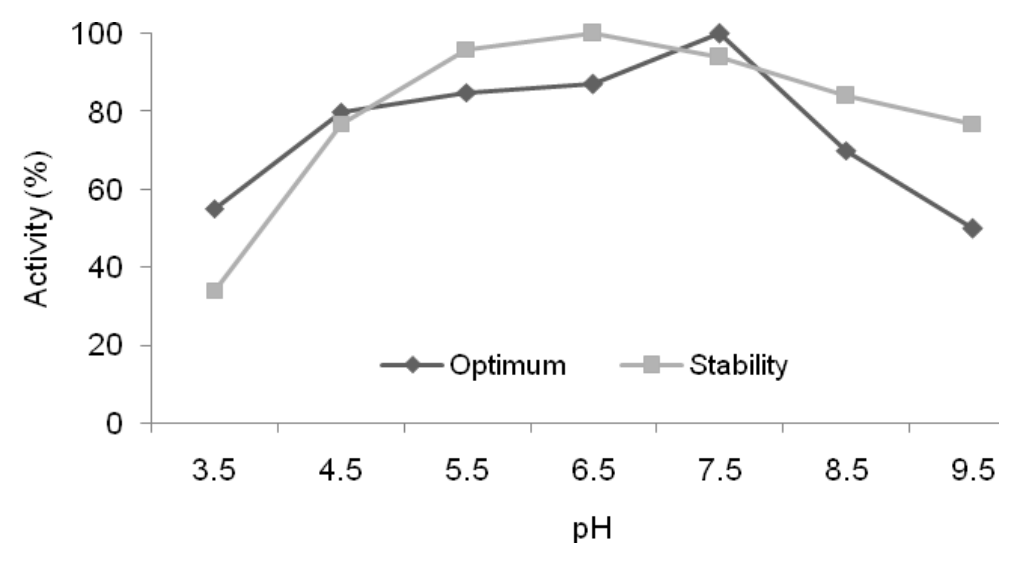

Figure 3 - Optimum pH and stability $\mathrm{pH}$ of Rhizobium sp. strain INPA R-926 amylase. Relative activity is expressed as a percentage of the maximum $(100 \%$ of enzyme activity $=1.9$ U.mL $\left.{ }^{-1}\right)$.

The rhizobia amylases were very stable, retaining more than $70 \%$ of their original activities in the range $\mathrm{pH} 4.5-9.5$ (Figs 3 and 4). The stability of amylase from the Rhizobium strain increased up to $\mathrm{pH} 6.5$ and then decreased gradually above this $\mathrm{pH}$ (Fig. 3). Above pH 5.5, the stability of amylase secreted by the Bradyrhizobium strain decreased significantly (Fig. 4). The amylase enzyme produced by the Rhizobium strain retained up to $94 \%$ of its original activity at $\mathrm{pH} 7.5$, while the enzyme from the Bradyrhizobium strain had a loss of $16 \%$ (Figs 3 and 4). Similar results have been found in other studies (Cordeiro et al., 2002; Gupta et al., 2003; Sajedi et al., 2005).

Effect of temperature on amylase activity and stability

The amylase from the Rhizobium strain showed good catalytic activity from 30 to $50{ }^{\circ} \mathrm{C}$, with an optimum temperature of $40{ }^{\circ} \mathrm{C}$ (Fig. 5). Above the optimum temperature, amylase activity decreased significantly. The relative activities at 50 and 60 ${ }^{\circ} \mathrm{C}$ were 65 and $55 \%$, respectively. Optimal temperatures were between 30 and $50{ }^{\circ} \mathrm{C}$ for amylase from the Bradyrhizobium strain (Fig. 6). At $60{ }^{\circ} \mathrm{C}$, however, a decrease of $37 \%$ in enzyme activity was registered. Several authors have reported that the majority of the bacterial amylases have an optimum temperature in the range of 30$100{ }^{\circ} \mathrm{C}$, with $\mathrm{pH}$ values between 4.6 and 9.0 (Pandey et al., 2000; Cordeiro et al., 2002; Gupta et al., 2003). Based in these studies, it could be inferred that the optimal temperatures found in this study were similar or lower than those described for other bacterial amylases. 


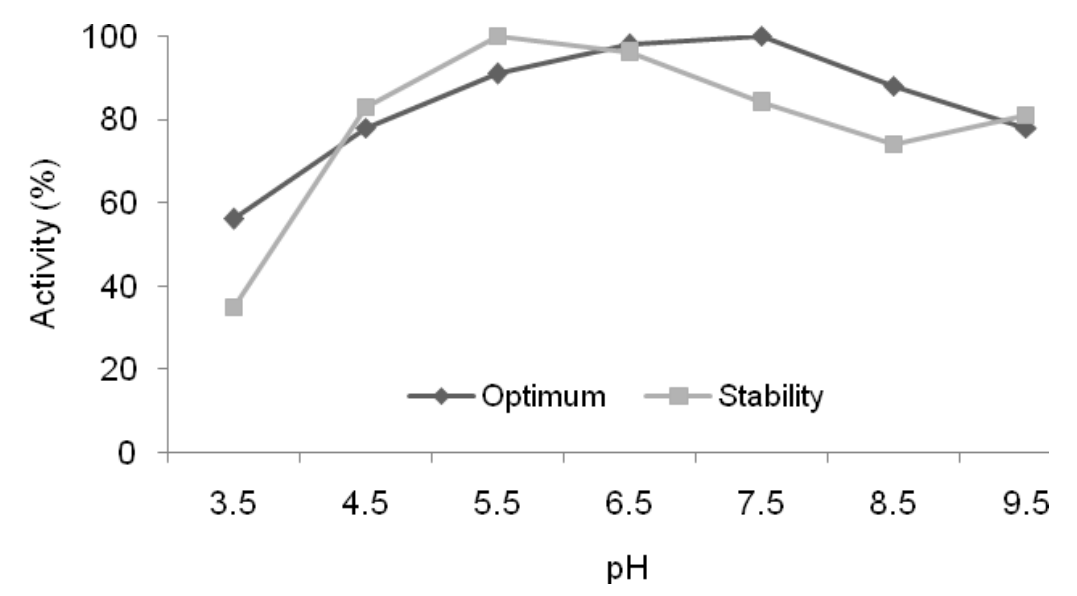

Figure 4 - Optimum pH and stability pH of Bradyrhizobium sp. strain INPA R-991 amylase. Relative activity is expressed as a percentage of the maximum (100\% of enzyme activity $=1.7$ U.mL-1).

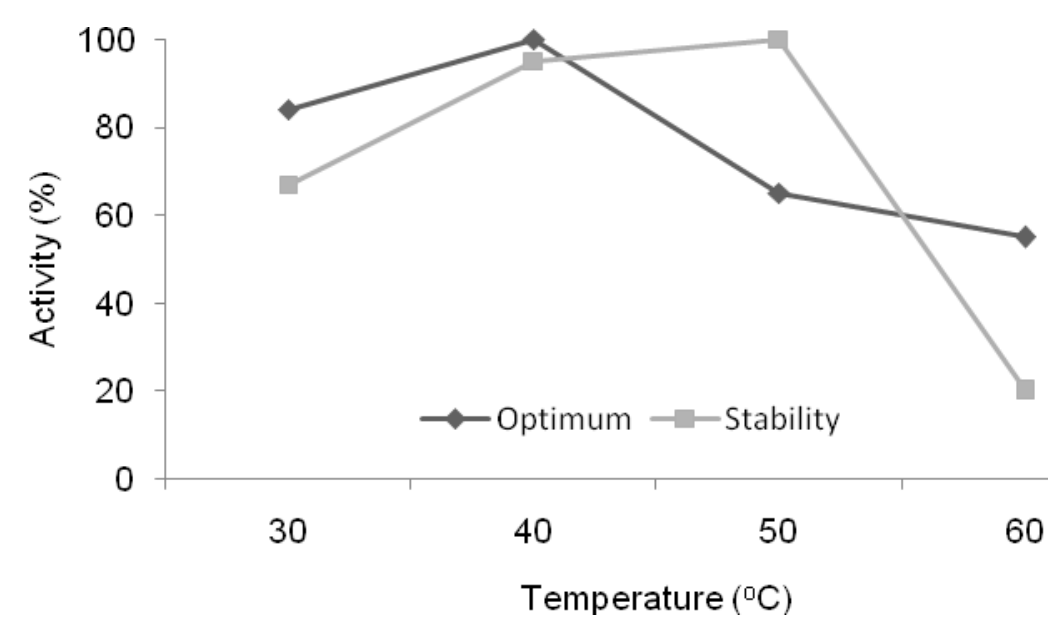

Figure 5 - Optimum temperature and stability temperature of Rhizobium sp. strain INPA R-926 amylase. Relative activity is expressed as a percentage of the maximum (100\% of enzyme activity $=2.6$ U.mL-1).

The amylase produced by the Rhizobium strain retained 95 and $100 \%$ of its original activity at 40 and $50{ }^{\circ} \mathrm{C}$, respectively (Fig. 5). Above $50{ }^{\circ} \mathrm{C}$, enzyme activity declined very sharply, possibly because of thermal inactivation. Similarly, amylase from the Bradyrhizobium strain was fully stable at $30{ }^{\circ} \mathrm{C}$, but lost 26,29 and $78 \%$ of its original activity at 40,50 and $60{ }^{\circ} \mathrm{C}$, respectively (Fig. 6). These data were comparable to the results documented by other researchers (Hamilton et al.,
1999; Pandey et al., 2000; Cordeiro et al., 2002; Bernhardsdotter et al., 2005).

\section{Effect of metal ions on amylase activity}

None of the metal ions evaluated was required for the activity of amylase from the Rhizobium strain (Table 2). The following metal ions had a slight inhibitory effect on enzyme activity: $\mathrm{Na}^{+}(5 \mathrm{mM})$, $\mathrm{Ca}^{2+}(5 \mathrm{mM}), \mathrm{Cu}^{2+}$ (1 and $\left.5 \mathrm{mM}\right), \mathrm{Mg}^{2+}(1$ and 5 $\mathrm{mM})$ and $\mathrm{Mn}^{2+}(1$ and $5 \mathrm{mM})$. On the other hand, 
stronger inhibitory effects were observed in the presence of $\mathrm{K}^{+}(5 \mathrm{mM})$ and $\mathrm{Hg}^{2+}$ ions $(5 \mathrm{mM})$ after 30 min incubation. Inhibitor effects of 30, 27, 24, 23 and $20 \%$ were observed in the presence of 1 $\mathrm{mM}$ of $\mathrm{K}^{+}, \mathrm{Hg}^{2+}, \mathrm{Na}^{+}, \mathrm{Ca}^{2+}$ and $\mathrm{Zn}^{2+}$, respectively. In addition, $\mathrm{Zn}^{2+}(5 \mathrm{mM})$ also inhibited enzyme activity by $21 \%$. Metal ions play a key role in protein folding or in catalysis.

Most amylases are known to be metal ion dependent enzymes (Pandey et al., 2000; Gupta et al., 2003; Ramachandran et al., 2004); in contrast,
Chakraborty et al. (2000) reported an amylase from Bacillus stearothermophilus whose activity was inhibited by divalent metal ions. Inhibition or no effect in the presence of some mono and trivalent cations ( $1 \mathrm{mM}, 5 \mathrm{mM}, 10 \mathrm{mM}$ or $50 \mathrm{mM}$ ) were also documented for amylases from Lactobacillus manihotivorans LMG 18010T (Aguilar et al., 2000), Bacillus amyloliquefaciens (Sarikaya and Gürgün, 2000), Bacillus sp. KSMK39 (Hagihara et al., 2001) and Bacillus sp. (Cordeiro et al., 2002).

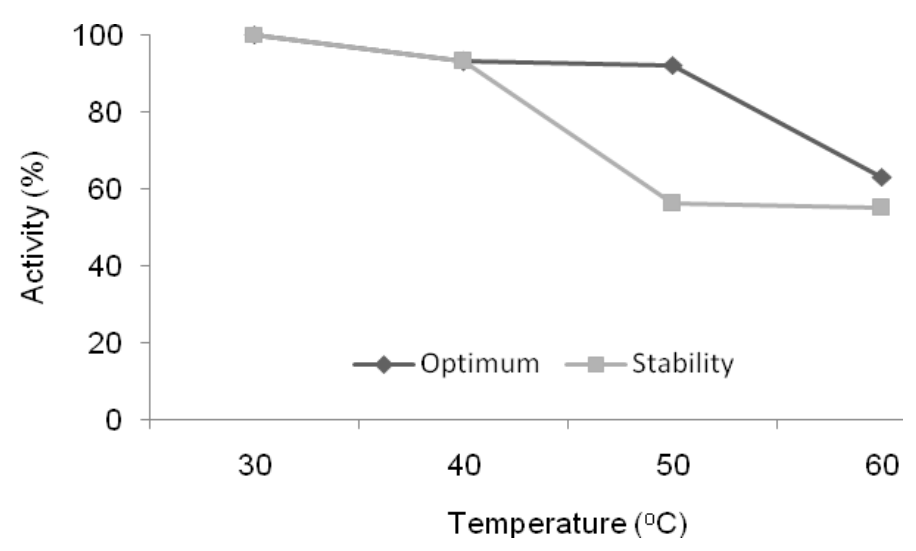

Figure 6 - Optimum temperature and stability temperature of Bradyrhizobium sp. strain INPA R991 amylase. Relative activity is expressed as a percentage of the maximum (100\% of enzyme activity $=2.5$ U.mL-1)

Table 2 - Influence of metal ions on amylase activities in indigenous rhizobia strains of Central Amazonian.

\begin{tabular}{lccc}
\hline Cationic ions & $\begin{array}{c}\text { Concentration } \\
(\mathbf{m M})\end{array}$ & $\begin{array}{c}\text { INPA R-926 } \\
\text { (Relative activity, \%) }\end{array}$ & $\begin{array}{c}\text { INPA R-991 } \\
\text { (Relative activity, \%) }\end{array}$ \\
\hline Control (No addition) & 0 & 100 & 100 \\
$\mathrm{~K}^{+}(\mathrm{KCl})$ & 1 & 70 & 137 \\
& 5 & 56 & 154 \\
$\mathrm{Na}^{+}(\mathrm{NaCl})$ & 1 & 76 & 72 \\
& 5 & 90 & 58 \\
$\mathrm{Ca}^{2+}\left(\mathrm{CaCl}_{2}\right)$ & 1 & 77 & 84 \\
& 5 & 87 & 77 \\
$\mathrm{Hg}^{2+}\left(\mathrm{HgCl}_{2}\right)$ & 1 & 73 & 137 \\
& 5 & 51 & 119 \\
$\mathrm{Mg}^{2+}\left(\mathrm{MgCl}_{2} \cdot 7 \mathrm{H}_{2} \mathrm{O}\right)$ & 1 & 87 & 88 \\
$\mathrm{Mn}^{2+}\left(\mathrm{MnSO}_{4}\right)$ & 5 & 87 & 91 \\
$\mathrm{Cu}^{2+}\left(\mathrm{CuSO}_{4} \cdot 5 \mathrm{H}_{2} \mathrm{O}\right)$ & 1 & 93 & 86 \\
$\mathrm{Zn}^{2+}\left(\mathrm{ZnSO}_{4} \cdot 7 \mathrm{H}_{2} \mathrm{O}\right)$ & 5 & 87 & 77 \\
& 1 & 85 & 88 \\
\end{tabular}

${ }^{\text {a }}$ Values are means of three triplicates. Relative activity is expressed as a percentage of the maximum (100\% of enzyme activity $=2.9$ U.mL ${ }^{-1}$ for strain INPA R-929 and 2.7 U.mL ${ }^{-1}$ for strain INPA R-991). 
Activity of amylase from the Bradyrhizobium strain was strongly stimulated by $\mathrm{K}^{+}$and $\mathrm{Hg}^{2+}$ (Table 2). The stimulatory effect of $\mathrm{K}^{+}$ions (5 and $10 \mathrm{mM}$ ) on amylase activity has been documented previously (Kekos and Macris, 1983; Pandey et al., 2000). In relation to $\mathrm{Hg}^{2+}$, present data contradicted the results obtained by others (Shih and Labbé, 1995; Aguilar et al., 2000; Cordeiro et al., 2002; Najafi et al., 2005). However, $1 \mathrm{mM}$ $\mathrm{Hg}^{2+}$ had no inhibitory effect on amylase activity of Bacillus sp. strain KSM-K38 (Hagihara et al., 2001). These results suggested that the effect of $\mathrm{Hg}^{2+}$ could vary among the microbial amylases, as observed for other heavy metal ions such as $\mathrm{Cd}^{2+}$, $\mathrm{Co}^{2+}, \mathrm{Fe}^{2+}$ and $\mathrm{Ni}^{2+}$ (Pandey et al., 2000; Lo et al., 2001; Dey et al., 2003). In addition, the presence

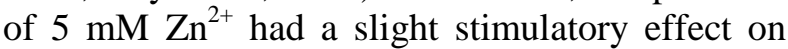
amylase activity (Table 2). On the other hand, activity was strongly or moderately reduced in the presence of $\mathrm{Na}^{+}(1$ and $5 \mathrm{mM}), \mathrm{Ca}^{2+}(5 \mathrm{mM})$ and $\mathrm{Mn}^{2+}(5 \mathrm{mM})$, while $\mathrm{Ca}^{2+}(1 \mathrm{mM}), \mathrm{Mg}^{2+}(1$ and 2 $\mathrm{mM}), \mathrm{Mn}^{2+}(1 \mathrm{mM}), \mathrm{Cu}^{2+}(1$ and $5 \mathrm{mM})$ and $\mathrm{Zn}^{2+}$ $(1 \mathrm{mM})$ showed a slight inhibitory effect on enzyme activity. These results differed from those of previous studies which showed that $\mathrm{Ca}^{2+} \mathrm{Mg}^{2+}$,
$\mathrm{Mn}^{2+}$ and $\mathrm{Na}^{+}$ions at a concentration of $5 \mathrm{mM}$ enhanced amylase activity (Shih and Labbé, 1995; Sarikaya and Gürgün, 2000; Bernhanrdsdotter et al., 2005; Najafi et al., 2005). However, a similar inhibitory effect of heavy metal ions such as $\mathrm{Cu}^{2+}$ and $\mathrm{Zn}^{2+}$ on amylase activity of Bacillus sp. strain TS-23 (Lin et al., 1998), B. subtilis (Sarikaya and Gürgün, 2000), B. thermooleovorans NP54 (Malhotra et al., 2000) and Bacillus sp. strain L1711 (Bernhanrdsdotter et al, 2005) has been reported.

\section{Effect of surfactants on amylase activity}

None of the surfactants tested had a pronounced inhibitory effect on enzyme activities. Only Triton X-100 showed a moderate inhibitory effect (14\%) on amylase activity of Rhizobium strain (Table 3). On the other hand, the addition of SDS (1\%) and Tween-80 (2\%) was found to stimulate activity by 9 and $21 \%$, respectively. SDS had a pronounced effect on amylase activity (65\%) of strain R-991, while Triton X-100 and Tween-80 at a concentration of $1 \mathrm{mM}$ increased activity by 6 and $22 \%$, respectively (Table 3 ).

Table 3 - Influence of surfactantes on amylase activities in indigenous rhizobia strains of Central Amazonian ${ }^{\mathrm{a}}$.

\begin{tabular}{lccc}
\hline Surfactants & $\begin{array}{c}\text { Concentration } \\
(\boldsymbol{\%})\end{array}$ & $\begin{array}{c}\text { INPA R-926 } \\
\text { (Relative activity, \%) }\end{array}$ & $\begin{array}{c}\text { INPA R-991 } \\
\text { (Relative activity, \%) }\end{array}$ \\
\hline Control (No addition) & 0 & 100 & 100 \\
SDS & 1 & 109 & 176 \\
& 2 & 94 & 165 \\
Triton X-100 & 1 & 86 & 106 \\
Tween-80 & 2 & 86 & 97 \\
& 1 & 97 & 122 \\
\hline
\end{tabular}

${ }^{a}$ Values are means of three triplicates. Relative activity is expressed as a percentage of the maximum (100\% of enzyme activity $=1.7 \mathrm{U} \cdot \mathrm{mL}^{-1}$ for the Rhizobium strain and $1.8 \mathrm{U} \cdot \mathrm{mL}^{-1}$ for the Bradyrhizobium strain).

The stimulatory effect of surfactants on amylase activity is controversial. Arnesen et al. (1998) reported a stimulatory effect of Tween-80 (1.3\%) on amylase activity of Thermomyces lanuginosus. In the same study, Triton X-100 had no beneficial effect. The activity of amylase was stimulated by the presence of Tween-80 (1\%) in Bacillus sp. (Oberoi et al., 2001). In another study, Triton X$100(0.1 \mathrm{mM})$ and Tween-80 $(0.05 \mathrm{mM})$ had weak stimulatory effects on amylase and pullulanase activities in Clostridium thermosulfurogenes (Reddy et al., 1999). Similar results were reported by Srisvastava and Baruah (1986) in $B$. stearothermophilus. On the other hand, addition of SDS $(0.03 \%)$ and Tween-80 has pronounced effects on amylase activity in Geobacillus thermoleovorans (Rao and Satyanarayana, 2003). A stimulatory effect of SDS (6\%) on amylase activity and stability in Bacillus sp. strain TS-23 was documented by Lo et al. (2001). From the previous reports and the present study, it was evident that the same surfactant could have different effect on the activity of the same enzyme in the same microorganism, or on the activity of different enzymes in the same microorganism, as previously discussed by Reddy et al. (1999). 


\section{Effect of inhibitors on amylase activity}

When EDTA $(5 \mathrm{mM})$ and $\mathrm{HgCl}_{2}(5 \mathrm{mM})$ were included in the reaction mixture, the enzyme activity of Rhizobium strain was reduced by 30 and $47 \%$, respectively (Table 4$)$. EDTA $(5 \mathrm{mM})$ was also found to reduce by $30 \%$ amylase activity of Bradyrhizobium strain (Table 4). In contrast and independently of the concentration tested, $\mathrm{HgCl}_{2}$ increased amylase activity of Bradyrhizobium strain. PMSF, a modifier of serine residues, either had no effect or stimulated activity of both rhizobia strains. Similar findings were reported for amylases from Bacillus strains TS-23 (97\%) (Lin et al., 1998), ANT-6 (103\%) (Buhan et al., 2003) and L1711 (91\%) (Bernhardsdotter et al., 2005).
The results of the present study suggested, at least in part, that $\mathrm{Ca}^{2+}$ ions and cysteine could be important for activity of the amylase from strain R-926. The importance of cysteine residues for catalysis was previously described for amylases independently of their origin (Pandey et al., 2000; Lo et al., 2001; Díaz et al., 2003).

From the results, it could concluded that the broad range of $\mathrm{pH}$ activity and stability profiles, optimum activity at lower $\mathrm{pH}$ and the high tolerance towards surfactants such as SDS, Triton X-100 and Tween-80 could make these rhizobial amylases attractive for both basic research and industrial biotechnological processes.

Table 4 - Influence of inhibitors on amylase activities in indigenous rhizobia strains of Central Amazonian ${ }^{\mathrm{a}}$.

\begin{tabular}{lccc}
\hline Inhibitors & $\begin{array}{c}\text { Concentration } \\
(\mathbf{m M})\end{array}$ & $\begin{array}{c}\text { INPA R-926 } \\
\text { (Relative activity, \%) }\end{array}$ & $\begin{array}{c}\text { INPA R-991 } \\
\text { (Relative activity, \%) }\end{array}$ \\
\hline Control (No addition) & 0 & 100 & 100 \\
EDTA & 1 & 85 & 81 \\
& 5 & 70 & 70 \\
$\mathrm{HgCl}_{2}$ & 1 & 79 & 137 \\
& 5 & 53 & 119 \\
$\mathrm{PMSF}$ & 1 & 111 & 94 \\
& 5 & 103 & 84 \\
\hline
\end{tabular}

$\overline{{ }^{a}}$ Values are means of three triplicates. Relative activity is expressed as a percentage of the maximum (100\% of enzyme activity $=1.4$ U.mL ${ }^{-1}$ for the Rhizobium strain and $1.5 \mathrm{U}_{\mathrm{mL}}^{-1}$ for the Bradyrhizobium strain).

\section{RESUMO}

A produção e parcial caracterização de extratos brutos de amilase de duas estirpes de rizóbio (R926 e R-991) foram avaliadas. Para ambas as estirpes, as máximas atividades amilolíticas foram obtidas no início/meio da fase exponencial de crescimento. As amilases rizobiais foram ativas numa variação de $\mathrm{pH}$ de 4,5 a 8,5 e temperatura de 30 a $50{ }^{\circ} \mathrm{C}$. Nenhum dos íons testados $\left(\mathrm{K}^{+}, \mathrm{Na}^{+}\right.$, $\mathrm{Ca}^{2+}, \mathrm{Hg}^{2+}, \mathrm{Mg}^{2+}, \mathrm{Mn}^{2+}, \mathrm{Cu}^{2+}$ e $\mathrm{Zn}^{2+}$ ) foi exigido para a atividade catalítica da estirpe R-926. A amilase produzida pelo R991 foi estimulada na presença de $\mathrm{K}^{+}, \mathrm{Hg}^{2+}$ e $\mathrm{Zn}^{2+}$. Os surfactantes SDS, Triton X-100 e Tween-80 não exerceram um pronunciado efeito inibitório sobre as atividades enzimáticas, e SDS e Tween-80 causaram os maiores efeitos estimulatórios. A atividade amilolítica rizobial foi reduzida em até $30 \%$ na presença de EDTA; a amilase produzida pela estirpe R-926 também foi inibida pelo $\mathrm{HgCl}_{2}$, sugerindo, ao menos em parte, a importância de $\mathrm{Ca}^{2+}$ e resíduos de cisteína na atividade amilolítica dessa estirpe.

\section{ACKNOWLEDGEMENTS}

The authors gratefully acknowledge the financial support from the Fundação de Amparo à Pesquisa do Estado do Amazonas (FAPEAM Process 624/04) and the Conselho Nacional de Desenvolvimento Científico e Tecnológico (CNPq Process 474007/2003-0). LAO is a CNPq fellow. They thank Dr. Charles Roland Clement (INPA/CPCA) for reviewing the English text.

\section{REFERENCES}

Aguilar, G.; Morlon-Guyot, J.; Trejo-Aguilar, B.; Guyot, J.P. (2000), Purification and characterization of an extracellular $\alpha$-amilase produced by Lactobacillus manihotivorans LMG 18010T, an amylolytic lactic acid bacterium. Enzyme Microb. Technol., 27, 406-413.

Arnesen, S.; Eriksen, S.H.; Olsen, J.; Jensen, B. (1998), Incresed production of alpha-amylase from Thermomyces lanuginosus by the addition of Tween80. Enzyme Microb. Techno., 23, 249-252. 
Bernharsdotter, E.C.M.J.; Ng, J.D.; Garriott, O.K.; Pusey, M.L. (2005), Enzymic properties of an alkaline chelator-resistanta-amylase from an alkaliphilic Bacillus sp. isolate L1711. Process Biochem., 40, 2401-2408.

Buonocore, V.; Poerio, E.; Silano, V.; Tomasi, M. (1976), Physical and catalytic properties of alphaamylase from Tenebrio molitor L. larvae. Biochem. J., 153, 621-625.

Burhan A.1.; Nisa, U.; Gokhan, C.; Omer, C.;Ashabil, A.; Osman, G. (2003), Enzymatic properties of a novel thermostable, thermophilic, alkaline and chelator resistant amylase from an alkaliphilic Bacillus sp. isolate ANT-6. Process Biochem., 38, 1397-1403.

Castro, G.R.; Mendez, B.S.; Siñeriz, F. (1993), Amylolytic enzymes produced by Bacillus amyloliquefaciens MIR-41 in bath and continuous culture. J. Chem. Technol. Biotechnol., 50, 289-294.

Castro, G.R.; Baigori, M.D.; Sineriz, F. (1999), Studies on $\alpha$-Amylase Production by Bacillus licheniformis MIR-61. Acta Biotechnol., 19, 263-272.

Cibis, E.; Krzywonos, M.; Trojanowska, K.; Miskiewicz, T.; Ryznar, A. (2004). Biodegradation of potato slops with a mixed population of bacteria of the genus Bacillus - Determination of the process conditions. Electronic Journal of Polish Agricultural Universities, Food Science and Technology. Available in: http://www.ejpau.media.pl/series/volume7/issue2/foo d/art-01.html.

Chakraborty K.; Bhattacharyya, B.K.; Sen, S.K. (2000), Purification and characterization of a thermostable alpha-amylase from Bacillus stearothermophilus. Folia Microbiol., 45, 207-210.

Cordeiro, C.A.M.; Martins, M.L.L.; Luciano, A.B. (2002), Production and properties of $\alpha$-amylase from thermophilic Bacillus sp. Braz. J. Microbiol., 33, 5761.

Davis, P.E.; Cohen, D.L.; Whitaker, A. (1980), The production of alpha amylase in batch and chemostatic culture. Antonie van Leenwenhoek, 46, 391-398.

Dey, G.; Bhupinder, S.; Banerjee, R. (2003), Immobilization of alpha-amylase produced by Bacillus circulans GRS 313. Braz. arch. biol. technol., 46, 167-176.

Díaz, A.; Sieiro, C.; Villa, T.G. (2003), Production and partial characterization of a $\alpha$-amylase by Xanthophyllomyces dendrorhous. Lett. Appl. Microbiol., 36, 203-207.

Glenn, A.R.; Dilworth, M.J. (1981), The uptake and hydrolysis of disaccharides by fast-and slow-growing species of Rhizobium. Arch. Microbiol., 129, 233239.

Gomes, I.; Gomes, J.; Steiner, W. (2003), Highly thermostable amylase and pullulanase of the extreme thermophilic eubacterium Rhodothermus marinus: production and partial characterization. Bioresource Techno., 90, 207-214.

Goyal, N.; Gupta, J.K.; Soni, S.K. (2005), A novel raw starch digesting thermostable alpha-amylase from Bacillus sp. I-3 and its use in the direct hydrolysis of raw potato starch. Enzyme Microb. Technol., 37, 723734.

Gornall, A.G.; Bardawill, C.J.; David, MM. (1949), Determination of serum proteins by mean of biuret reaction. J. Biol. Chem., 177, 751-756.

Gupta, R.; Gigras, P.; Mohapatra, H.; Goswami, V.K.; Chauhan, B. (2003), Microbial $\alpha$-amylases: a biotechnological perspective. Process Biochem. 38, 1599-1616.

Hagihara, H.; Igarashi, K.; Hayashi, Y.; Endo, K.; Ikawa-Kitayama, Ozaki, K.; Kawai, S.; Ito, S. (2001), Novel $\alpha$-amylase thatis highly resistant to chelating reagents and chemical oxidants from the alkaliphilic Bacillus isolate KSM-K38. Appl. Environ. Microbiol., 67, 1744-1750.

Hamilton, L.M.; Kelly, C.T.; Fogarty, W.M. (1999), Production and properties of the raw starch -digesting alpha-amylase of Bacillus sp. IMD 435. Process Biochemistry, 35, 27-31.

Jimenéz-Zurdo, J.; Mateos, P.F.; Dazzo, F.B.; Martínez-Molina, E. (1996), Cell-bound cellulase and polygalacturonase production by Rhizobium and Bradyrhizobium species. Soil Biol. Biochem., 28, 917-921.

Jorgensen, S.; Vorgias, C.E.; Antranikian, G. (1997), Cloning, sequencing, characterization, and expression of an extracellular alpha-amylase from the hyperthermophilic archaeon Pyrococcusfuriosus in Escherichia coli and Bacillus subtilis. J. Biol. Chem., 272, 335-342.

Kekos, D.; Macris, B.J. (1983), Production and characterization of amylase from Calvatia gigantea. Appl. Environ. Microbiol., 45, 935-941.

Kim, T.U.; Gu, B.G.; Jeong, J.Y.; Byun, S.M.; Shin, Y.C. (1995), Purification and characterization of a maltotetraose-forming alkaline $\alpha$-amylase from an alkalophilic Bacillus strain, GM8901. Appl. Environ. Microbiol., 61, 3105-3112.

Lin, L-L.; Chyau, C-C.; Hsu, W-H. (1998), Production and properties of a raw-starch-degrading amylase from the thermophilic and alkaliphilic Bacillus sp. TS-23. Biotechnol. Appl. Biochem., 28, 61-68.

Leveque, E.; Haye, B.; Belarbi, A. (2000), Cloning and expressionof an a-amylase encoding gene from the hyperthermophi-lic archaebacterium Thermococcus hydrothermalis and bioche-mical characterization of the recombinant enzyme. FEMS Microbiol. Lett., 186, 67-71.

Lo, F-H.;. Lin, L-L.; Chen, H-L.; Hsu, W-H.; Chang, CT. (2001), Enzymatic properties of a SDS-resistant Bacillus sp. TS-23 $\alpha$-amylase produced by recombinant Escherichia coli. Process Biochem., 36, 743-750. 
Malhotra, R.; Noorwez, S.M.; Satyanarayana, T. (2000), Production and Partial characterization of thermostable and calcium-independent $\alpha$-amylase of an extreme thermophile Bacillus thermoleovorans NP54. Lett. Appl. Microbiol., 31, 378-384.

Matzke, J.; Schwermann, B.; Bakker, E.P. (1997), Acidostable and acidophilic proteins: the example of the alpha-amylase from Alicyclobacillus acidocaldarius. Comp. Biochem. Physiol. Part A: Mol. Integr. Physiol., 118, 475-479.

Najafi, M.F.; Kembhavi, A. (2005), One step purification and characterization of an extracellular $\alpha-$ amylase from marine Vibrio sp. Enzyme Microb. Technol., 36, 535-539.

Nelson, N. (1944), A photometric adaptation of the Somogyi method for the determination of glucose. $J$. Biol. Chem., 153, 375-380.

Oberoi, R.; Beg, Q.K.; Puri, S.; Saxena, R.K.; Gupta, R. (2001), Characterization and wash performance analysis of a SDS-stable alkaline protease from Bacillus sp. W. J. Microbiol. Biotechnol., 17, 493497.

Ohdan, K.; Kuriki, T.; Kaneko, H.; Shimada, J.; Takada, T.; Fujimoto, Z.; Mizuno, H.; Okada, S. (1999), Characteristics of two forms of alphaamylases and structural implication. Appl. Environ. Microbiol., 65, 4652-4658.

Oliveira, A.N.; Oliveira, L.A.; Andrade, J.S.; ChagasJúnior, A.F. (2006), Atividade enzimática de isolados de rizóbia nativos da Amazônia Central crescendo em diferentes níveis de acidez. Ci. Tecnol. Alim., 26, 204-210.

Oliveira, A.N.; Oliveira, L.A.; Andrade, J.S.; ChagasJúnior, A.F. (2007). Rhizobia amylase production using various starchy substances as carbon substrates. Braz. J. Microbiol., 38, 208-216.

Pandey, A.; Nigam, P.; Soccol, C.R.; Soccol, V.T.; Singh, D.; Mohan, R. (2000), Advances in microbial amylases. Biotechnol. Appl. Biochem., 31, 135-152.

Rahman, R.N.Z.R.A.; Geok, L.P.; Basri, M.; Salleh, A.B. (2005). An organic solvent-tolerant protease from Pseudomonas aeruginosa strain K: Nutritional factors affecting protease production. Enzyme Microb. Technol., 36, 749-757.

Ramachandran; S.; Patel, A.K.; Nampoothiri, K.M.; Chandran, S.; Szakacs, G.; Soccol, C.R.; Pandey, A. (2004), Alpha amylase from a fungal culture grown on oil cakes and its properties. Braz. arch. biol. technol., 47, 309-317.
Rao, J.L.U.M.; Satyanarayana, T. (2003). Statistical optimization of a high maltose-forming, hyperthermostable and $\mathrm{Ca}^{+2}$-independent $\alpha$-amylase production by an extreme thermophile Geobacillus thermoleovorans using response surface methodology. J. Appl. Microbiol., 95, 712-718.

Reddy, P.R.M.; Swamy, M.V.; Seenayya, G. (1999), Purification and characterization of thermostable $\alpha$ amylase and pullulanase from high-yielding Clostridium thermosulfurogenes SV2. W. J. Microbiol. Biotechnol., 14, 89-94.

Sarikaya, E.; Gürgün, V. (2000), Increase of the $\alpha$ amylase yield by some Bacillus strains. Turk. J. Biol., 24, 299-308.

Shin, N-J.; Labbé, R.G. (1995), Purification and characterization of an extracellular alpha-amylase from Clostridium perfringens Type A. Appl. Environ. Microbiol., 61, 1776-1779.

Srivastava R.A.K.; Baruah, J.N. (1986), Culture conditions for Production of thermostable amylase by Bacillus stearothermophilus. Appl. Environ. Microbiol., 52, 179-184.

Stamford, T.L.M.; Stamford, N.P.; Coelho, L.C.B.B.; Araújo, J.M. (2001), Production and characterization of a thermostable $\alpha$-amylase from Nocardiopsis sp. endophyte of yam bean. Bioresource Technol., 76, 137-141.

Sunna, A.; Hashwa, F. (1990), Thermostable amylase from an aerobic Gran-negative, nonspore forming thermophilic bacteria. Biotechnol. Lett., 12, 433-438.

Toffanin, A.; Cadahia, E.; Ruiz-Argüeso, J.I.; Palacios, J.M. (2002), Characterization of the urease gene cluster from Rhizobium leguminosarum bv. viciae. Arch. Microbiol., 177, 290-298.

Vihinen, M.; Mäntsälä, P. (1989), Microbial amylolytic enzymes. Crit. Rev. Biochem. Mol. Biol., 24, 329418.

Vincent, J.M. (1970), A manual for the practical study of root-nodules bacteria. Oxford, UK: Blackwell Science Publication. 164p.

Wijbenga, D.J.; Beldman, G.; Veen, A.; Binnema, D.L. (1991), Production of native-starch-degrading enzymes by a Bacillus firmus/lentus strain. Appl. Microbiol. Biotechnol., 35, 180-184.

Received: Janeiro 04, 2007; Revised: September 03, 2007; Accepted: April 14, 2009. 